\title{
Internal tidal mixing as a control on continental margin ecosystems.
}

Jonathan Sharples ${ }^{1}$, C. Mark Moore ${ }^{2}$, Anna E. Hickman ${ }^{3}$, Patrick M. Holligan², Jacqueline F. Tweddle ${ }^{4}$, Matthew R. Palmer ${ }^{1}$, \& John H. Simpson ${ }^{5}$.

${ }^{1}$ Natural Environment Research Council, Proudman Oceanographic Laboratory, 6 Brownlow Street, Liverpool L3 5DA, United Kingdom.

${ }^{2}$ National Oceanography Centre, University of Southampton, Empress Dock, Southampton SO14 3ZH, United Kingdom.

${ }^{3}$ Department of Earth and Ocean Sciences, University of Liverpool, Liverpool, L69 3GP, United Kingdom.

${ }^{4}$ Department of Earth Sciences, Boston University, Boston, MA 02215, USA

${ }^{5}$ School of Ocean Sciences, Bangor University, Menai Bridge, Anglesey LL59 5AB, United Kingdom.

Corresponding author: Jonathan Sharples, j.sharples@pol.ac.uk

Keywords: shelf break, internal tide, phytoplankton, fisheries, carbon export Running head: Internal tides and shelf edge ecosystems.

Published as:

Sharples, J., C. M. Moore, A. E. Hickman, P. M. Holligan, J. F. Tweddle, M. R. Palmer, and J. H. Simpson, 2009. Internal tidal mixing as a control on continental margin ecosystems. Geophys. Res. Lett., 36, L23603, doi:10.1029/2009GL040683. 


\begin{abstract}
.
We show that a breaking internal tide at a shelf edge is a fundamental control on the structural and functional properties of ecosystems. Contrasts in vertical mixing of nitrate between the shelf and the open ocean correspond with horizontal and vertical changes in phytoplankton communities, with largest cells found in surface waters at the shelf edge. Intense fishing activity is commonly seen at continental shelf edges, targeting spawning fish stocks. We suggest that the internal tide, a globally ubiquitous physical process at steep shelf edge bathymetry, supports shelf edge fisheries by providing large-celled phytoplankton for first-feeding fish larvae. The repeatability of the internal tide removes fish from the need to time spawning with a spring bloom. Also, with large phytoplankton cells dominating particulate organic carbon export, the internal tides could be an important influence on spatial and temporal variability in patterns of global carbon sequestration in deep water and sediments.
\end{abstract}

\title{
1. Introduction.
}

The size of phytoplankton cells plays an important role in determining how organic carbon is transferred to higher trophic levels or is exported to deep water (Legendre and Rivkin, 2002). Communities made up of small $(<5 \mu \mathrm{m})$ cells recycle carbon within the microbial food web, restricting the amount of carbon available to larger organisms. By contrast, large phytoplankton cells lead to greater downward export of particulate organic carbon (POC) (Boyd and Newton, 1999; Legendre and Rivkin, 2002). Also they are more likely to be grazed directly by larger zooplankton, including fish larvae (Cushing, 1995), so increasing the efficiency of energy transfer to higher trophic levels.

Phytoplankton communities are generally dominated by small cells in nutrient-poor environments (Irwin et al., 2006), where small size provides an intrinsic advantage in nutrient uptake (Munk and Riley, 1952; Chisholm, 1992). Larger cells are associated with nutrient-replete conditions, such as temperate spring blooms and upwelling regions (e.g. Pingree et al., 1976; Chavez et al., 1991), where the alleviation of nutrient stress removes the competitive advantage of being small. The edges of continental shelves are frequently sites of internal tides and elevated vertical mixing (Baines, 1974) driving vertical nitrate fluxes (Sharples et al., 2001a; Sharples et al., 2007). They are also sites of high fish and fish larva densities (Genin, 2004), and are recognized as important contributors to the global carbon cycle (Walsh, 1991). Here we show that vertical nitrate fluxes driven by an internal tide at the shelf edge of the Celtic Sea (Fig. 1) underpin horizontal and vertical gradients in the phytoplankton community structure, providing a new explanation for the distribution of fishing activity and having implications for the export of particulate organic carbon (POC).

\section{Horizontal gradients in vertical turbulent mixing and nutrient fluxes.}

Using a free-fall turbulent shear profiler during neap-tide and spring-tide 25-hour sampling periods (Sharples et al., 2007) at the shelf edge of the Celtic Sea (position CS2, Fig. 1) we have measured dailymean vertical turbulent diffusivities of $1-7 \times 10^{-4} \mathrm{~m}^{2} \mathrm{~s}^{-1}$ at the base of the sub-surface chlorophyll layer. High spring tide diffusivities were driven by packets of internal solitons, with diffusivities reaching $3 \times 10^{-3}$ $\mathrm{m}^{2} \mathrm{~s}^{-1}$. Further on the shelf (position OB, Fig. 1) daily-mean vertical diffusivities at the base of the chlorophyll layer were $2-7 \times 10^{-6} \mathrm{~m}^{2} \mathrm{~s}^{-1}$, similar to other values in stratified regions of the NW European shelf (Rippeth, 2005). Diffusivities within the thermocline of the open ocean are typically $\sim 10^{-5} \mathrm{~m}^{2} \mathrm{~s}^{-1}$ (Lewis et al., 1986; Planas et al., 1999).

This mixing drives a vertical turbulent flux of nitrate into the base of the thermocline, where it fuels new production. At station OB we observed a daily mean flux of $2 \mathrm{mmol} \mathrm{m}^{-2} \mathrm{~d}^{-1}$ into the thermocline, similar to other reports in the region (Sharples et al., 2001b). By contrast, estimates of mean daily nitrate fluxes into the sub-surface chlorophyll layer of the open Atlantic Ocean range between $0.05-0.14 \mathrm{mmol} \mathrm{m}^{-}$ ${ }^{2} \mathrm{~d}^{-1}$ (Lewis et al., 1986; Planas et al., 1999). At the Celtic Sea shelf edge nitrate fluxes at spring tides (up to 
$9 \mathrm{mmol} \mathrm{m} \mathrm{m}^{-1}$ ) are almost an order of magnitude greater than at neaps $\left(1-2 \mathrm{mmol} \mathrm{m}^{-2} \mathrm{~d}^{-1}\right.$ ) (Sharples et al., 2007). Measurements of primary production showed a factor 2 increase in carbon fixation rates at the shelf edge compared to the Celtic Sea and NE Atlantic, with single samples from the peak of the chlorophyll layer showing larger-celled phytoplankton at the shelf edge (Sharples et al., 2007).

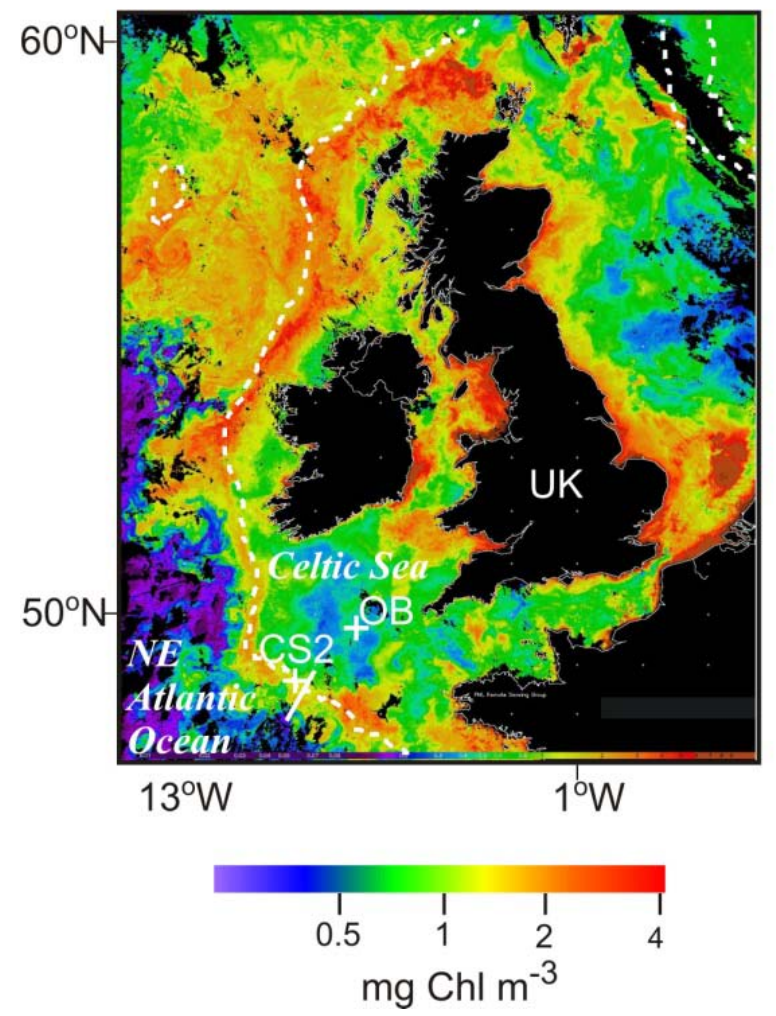

Figure 1.

Typical early summer sea surface chlorophyll image of seas around the UK and Ireland (MODIS composite $27^{\text {th }}$ May $-2^{\text {nd }}$ June 2004). The dashed white line is the shelf edge (200 metre isobath), illustrating the correspondence with a band of high chlorophyll surface waters around much of the UK and Irish shelf. The solid white line SW of the UK was the transect used for the sampling in July 2005 (Fig. 2). Turbulent mixing and nitrate flux data from a 25-hour station are presented for station OB; station CS2 is the shelf break position used for the measurements of Sharples et al., 2007. Satellite imagery courtesy of NEODAAS, Plymouth Marine Laboratory, UK. Bathymetry information is from the General Bathymetric Chart of the Oceans (GEBCO).

\section{The phytoplankton response.}

We present here more detailed data on the phytoplankton community along the transect between the Celtic Sea and the open NE Atlantic Ocean (Fig. 1), showing marked vertical and horizontal gradients (Fig. 2). The distribution of temperature and chlorophyll illustrates the localised nature of shelf edge mixing by the internal tide (Fig. 2A). Despite the inference of the satellite chlorophyll imagery (Fig. 1) there was no clear shelf edge increase in the phytoplankton biomass integrated between the sea surface and 100 metres (Fig. 2B). However, the proportion of biomass in the larger size classes, including the diatoms, was higher at the shelf edge with $60 \%$ of the phytoplankton biomass consisting of cells $>5 \mu$ m diameter (Fig. 2C). A more dramatic phytoplankton response to conditions at the shelf edge is illustrated by the distribution of different phytoplankton groups, based on flow cytometry. The prokaryotes Prochlorococcus (cells $0.5-0.7 \mu \mathrm{m}$ diameter, Fig. 2D) and Synechococcus (0.8 - $1.5 \mu \mathrm{m}$, Fig. 2E) dominated the thermocline of the NE Atlantic Ocean, with small numbers of autotrophic picoeukaryotes ( $2-5 \mu$ m diameter, Fig. $2 \mathrm{~F})$ in the surface layer. On the shelf the picoeukaryotes had a biomass maximum within the thermocline, with Synechococcus dominating the surface layer and almost no Prochlorococcus present. At the shelf edge there was almost a complete absence of prokaryotes; instead the thermocline and surface waters were dominated by picoeukaryotes (Fig. 2F) and other larger phytoplankton (Fig. 2C).

These distinct horizontal contrasts in the vertical structure of phytoplankton correspond to the contrasts in the supply of nitrate. The localised site of very strong vertical nitrate flux at the shelf edge shifted the phytoplankton community to one containing large cells, particularly close to the sea surface, with 
a marked near absence of prokaryotes. Intermediate nitrate fluxes into the thermocline on the shelf led to small eukaryotes in the thermocline, and Synechococcus residing in the upper layer where their smaller size may be advantageous in the nitrate-deplete regeneration-dominated surface waters. Note that the phytoplankton community at the Celtic Sea end of this transect was representative of the community throughout the rest of the stratified Celtic Sea, including station OB (Hickman et al., 2009). In the oligotrophic open ocean, influenced by very low nitrate supplies, the cyanobacteria, particularly Prochlorococcus, dominated the thermocline phytoplankton, as observed widely in the temperate NE Atlantic in summer (Tarran et al., 2001).
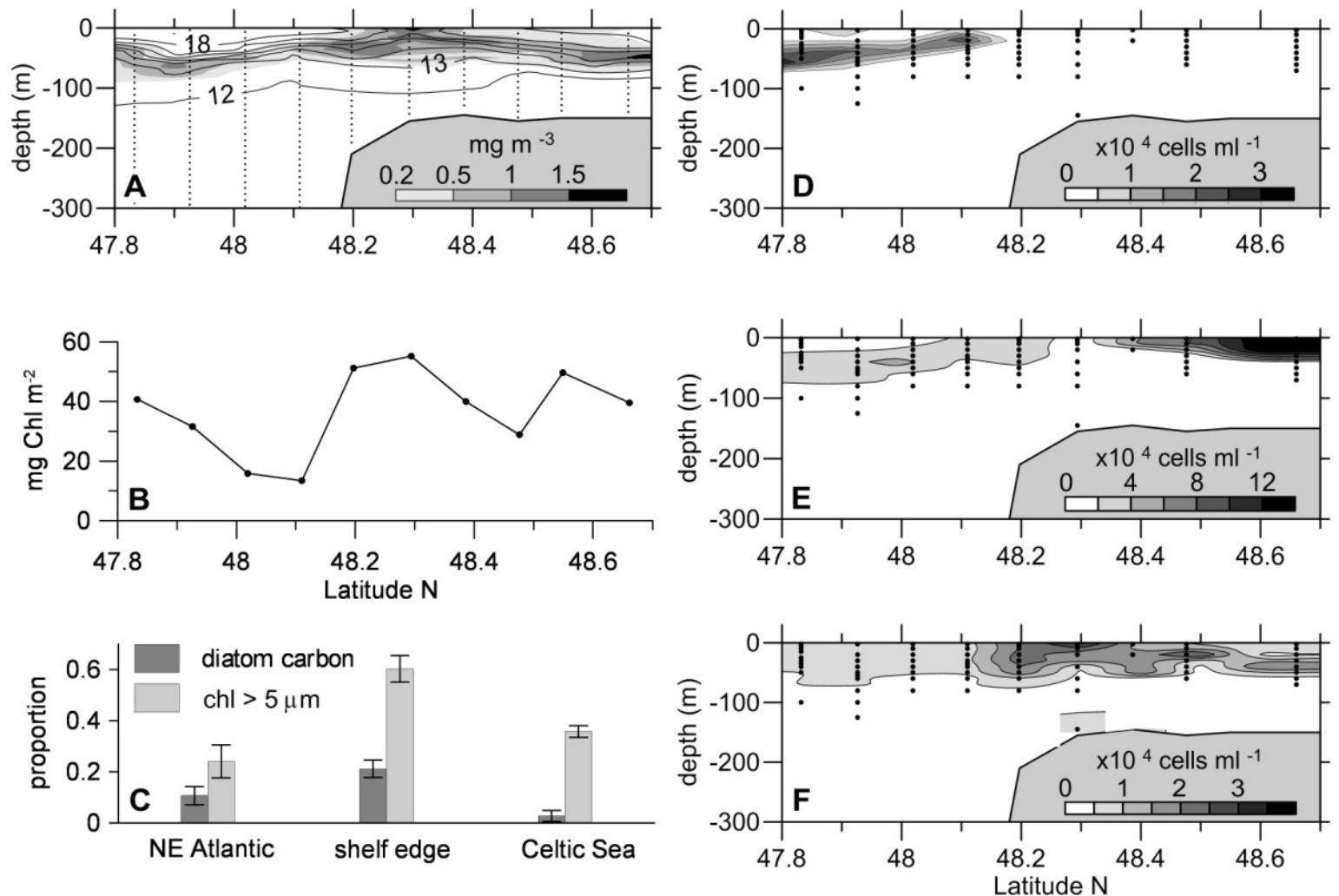

Figure 2.

Distributions of chlorophyll and phytoplankton along the transect marked in Fig. 1.

A: Temperature (lines) and chlorophyll concentration (shaded) across the shelf edge (adapted from Sharples et al., 2007). B: chlorophyll integrated through the upper 100 metres. C: the proportions of upper $100 \mathrm{~m}$ chlorophyll in the $>5 \mu \mathrm{m}$ size fraction, and the proportion of carbon within the diatoms in the open NE

Atlantic, at the shelf edge, and in the Celtic Sea. D: the prokaryote Prochlorococcus.

E: the prokaryote Synechococcus. F: picoeukaryotes. In A the sampling positions are marked by the vertical dotted lines, with adjacent positions being approximately $10 \mathrm{~km}$ apart. In $\mathrm{C}$ the fraction of chlorophyll biomass in cells $>5 \mu \mathrm{m}$ is based on size-fractionated filtering of water samples, and phytoplankton carbon was estimated following (Poulton et al., 2007; Zubkov et al., 2000); error bars are \pm 1 s.d.. In D, E and F the dots show positions of water samples used for the flow cytometer analysis.

\section{Impacts on shelf edge fish and fishing.}

The shelf edge band of surface chlorophyll, indicating the site of internal tidal mixing, can often be seen stretching from northern Biscay, around the west of Ireland, and along the Malin shelf edge west of Scotland (Fig. 1). We expect the patterns seen in Fig. 2 will be characteristic of this larger feature. The shelf edge is a site of high fishing vessel activity in the UK sector of the Celtic Sea (Fig. 3A), and further between the Bay of Biscay and northern Scotland. Vessels target spawning stocks of mackerel, horse mackerel, hake, blue whitting and anchovies (Reid, 2001; ICES, 2007). Based on the distribution of eggs and larvae, the spawning habitat of these species is very tightly associated with the 200 metre isobath at the shelf edge (Ibaibarriaga et al., 2007). High fish concentrations along continental margins are often explained in terms 
of a nutrient supply fuelling enhanced primary production, supporting high densities of physicallyaggregated zooplankton, ultimately providing more food for fish (Genin, 2004). While shelf edge primary production rates are higher (Sharples et al., 2007), analysis of data from the Continuous Plankton Recorder indicates that there is no response in standing stocks of components of the meso-zooplankton known to be part of larval diet (Fig. 3B, C, D). Fish larvae target particles $>5 \mu \mathrm{m}$ in size (Cushing, 1995) and data on mackerel larval gut contents at the Celtic Sea shelf edge shows first-feeding larvae to be ingesting phytoplankton (Conway et al., 1999). Rather than higher phytoplankton and zooplankton biomass or production, it would appear that the internal tide could be an underlying cause of the distribution of spawning fish via the impact of vertical turbulent mixing on the size structure of the phytoplankton community.
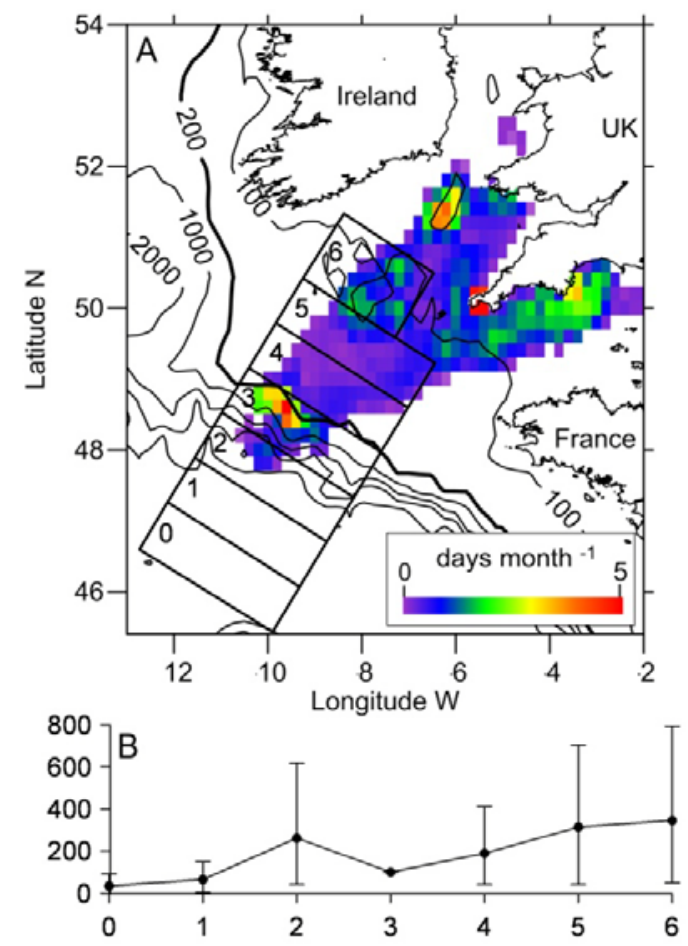

Figure 3.

A: Annual average (2001-2007) of fishing vessel activity in the UK sector of the Celtic Sea for the thermally-stratified period April - September, based on analysis of Vessel Monitoring System (VMS) data provided by the UK Department for Environment, Food and Rural Affairs. VMS position data for all EU fishing vessels was used to calculate vessel speeds, with speeds $<4$ knots taken to imply fishing activity (e.g. Hiddink et al., 2007). Boxes $0-6$ were used for the collation of plankton samples from the Continuous Plankton

Recorder (CPR) for (B) copepod eggs, (C) copepod nauplii, and (D) small copepods $<2 \mathrm{~mm}$ length. Monthly total counts in each box for the years 1990-2006 were obtained from the Sir Alister Hardy Foundation for Ocean Science (SAHFOS). The CPR data are illustrated in terms of their mean densities relative to the

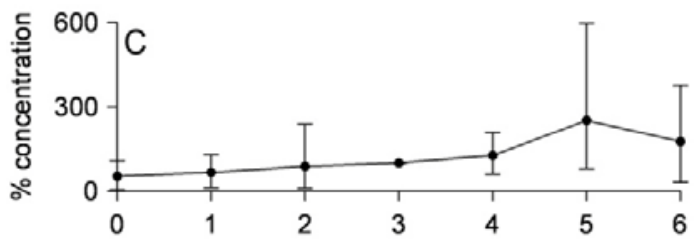
concentration in box 3 (the shelf edge and upper slope). Error bars are 1 s.d.. Note that CPR samples are taken from a nominal depth of 10 metres. For non-motile or weakly motile mesozooplankton components, in the strong vertical

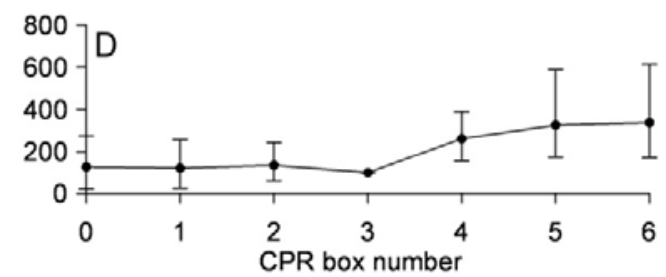

mixing at the shelf edge, this will not significantly impact the interpretation of the CPR data.

Similarly, while the near-surface CPR data on small components of the meso-zooplankton did not show any shelf edge signal, overall zooplankton communities have been found to change at the shelf edge, though not as a response to changes in primary production rates (Albaina \& Irigoien, 2004). This perhaps again implicates the phytoplankton community in determining the environment for larger organisms. The internal tide operates with regular periodicity throughout the stratified season (typically April - September). As a control on larval food the internal tide removes the fish from a need to time spawning with the annual spring bloom (Cushing, 1990; Platt et al., 2003), though species-specific constraints due to temperature and light will still play roles in determining preferred spawning season. This proposed link between periodic (springneap) supply of nitrate, growth of larger phytoplankton cells, and feeding by fish larvae is comparable to the 
observations of Lasker, 1975, on the role of episodic wind mixing supporting sardine larvae off California. In addition to food for first-feeding larvae the mixing and nitrate flux at the shelf edge could be aiding fish survival in other ways. The nutrient supply and subsequent large-celled phytoplankton could offer better quality food for fish larvae than a cyanobacteria-dominated community (Muller-Navarra et al., 2000). Increased turbulent mixing at the shelf edge may also play a role in prey capture rates by fish larvae (Kiorboe and Saiz, 1995).

Internal tidal mixing is a globally common process over shelf edges, seamounts, and other topographic features. The frequent association of important fisheries over the same topography suggests that our observations of the impact of mixing on the phytoplankton community structure is an important, and so far unreported, link between physical processes and ecosystem function.

\section{A role in particulate organic carbon (POC) export at the shelf edge.}

Large celled phytoplankton are a major component of POC exported out of the photic zone (Legendre and Rivkin, 2002). The ocean margins are thought to be important sites of POC sequestration as carbon can reach the sediments and be buried before being remineralised (Walsh, 1991). Based on satellite imagery of sea surface chlorophyll, margins have been estimated to be responsible for $>40 \%$ of global oceanic carbon sequestration (Muller-Karger et al., 2005). Our results suggest that the edges of continental shelves are not only sites of relatively high primary production, but also support a phytoplankton community of large cells more suited to export and sequestration of carbon. Our demonstration of phytoplankton cell size being sensitive to gradients in physical mixing suggests that knowledge of baroclinic energy dissipation globally (e.g. Nycander, 2005) could be a valuable component in explaining present-day community structure and potential for POC export. On longer time scales the distribution of internal tides will alter as sea level changes between glacial and inter-glacial periods, or as the shape and length of margins changes due to different continental configurations. These may be important considerations for long term changes in shelf edge ecosystems and global carbon sequestration.

\section{Acknowledgements.}

This work was funded by the UK Natural Environment Research Council, grant numbers NER/A/S/2001/00449, NER/A/S/2001/00961 and Oceans2025. Our thanks to the UK National Marine Facilities, and the crew of the RRS Charles Darwin (cruise CD173). David Johns, SAHFOS, provided the CPR data used in Fig. 4; Alex Poulton (National Oceanography Centre, Southampton) carried out the analysis of phytoplankton carbon; Ross Holland and Mike Zubkov (National Oceanography Centre, Southampton) are thanked for assistance with flow cytometry analysis.

\section{References.}

Albaina, A., and X. Irigoien (2004), Relationships between frontal structures and zooplankton communities along a cross-shelf transect in the Bay of Biscay (1995 to 2003). Marine Ecology Progress Series, 284, 65-75.

Baines, P. G. (1974), Generation of internal tides over steep continental slopes. Philosophical Transaction of the Royal Society London, A227, 27-58.

Boyd, P. W., and P. P. Newton (1999), Does planktonic community structure determine downward particulate organic carbon flux in different oceanic provinces? Deep-Sea Research I, 46, 63-91.

Chavez, F. P., R. T. Barber, P. M. Kosro, A. Huyer, S. R. Ramp, T. P. Stanton, and B. R. Demendiola (1991), Horizontal transport and the distribution of nutrients in the coastal transition zone off northern California - effects on primary production, phytoplankton biomass and species composition, Journal of Geophysical Research, 96, 14833-14848. 
Chisholm, S. W. (1992), Phytoplankton size. In: Primary Productivity and Biogeochemical Cycles in the Sea. (Eds. P. G. Falkowski \& A. D. Woodhead), Plenum Press, New York, 550pp.

Conway, D. V. P., S. H. Coombs, J. A. Lindley, and C. A. Llewellyn (1999), Diet of mackerel (Scomber scombrus) larvae at the shelf-edge to the south-west of the British Isles and the incidence of piscivory and coprophagy. Vie et Milieu, 49, 213-220.

Cushing, D (1990), Plankton production and year-class strength in fish populations - an update of the match mismatch hypothesis. Advances in Marine Biology, 26: 249-293.

Cushing, D (1995), Population Production and Regulation in the Sea: a Fisheries Perspective, Cambridge University Press, Cambridge.

Genin, A. (2004), Bio-physical coupling in the formation of zooplankton and fish aggregations over abrupt topographies, Journal of Marine Systems, 50, 3-20.

Hickman, A.E., P. M. Holligan, C. M. Moore, J. Sharples, V. Krivtsov, M. R. Palmer (2009), Distribution and chromatic adaptation of phytoplankton within a shelf sea thermocline, Limnology and Oceanography, 54, 525-536.

Hiddink, J. G., S. Jennings, and M. J. Kaiser (2007), Assessing and predicting the relative ecological impacts of disturbance on habitats with different sensitivities, Journal of Applied Ecology, 44, 405413.

Ibaibarriaga, L., X. Irigoien, M. Santos, L. Motos, J. M. Fives, C. Franco, A. L. De Lanzos, S. Acevedo, M. Bernal, N. Bez, G. Eltink, A. Farinha, C. Hammer, S. A. Iversen, S. P. Milligan, D. G. Reid (2007), Egg and larval distributions of seven fish species in north-east Atlantic waters, Fisheries Oceanography, 16, 284-293.

ICES (2007), Report of the Working Group for Regional Ecosystem Description (WGRED), ICES Headquarters, Copenhagen. ICES CM 2007/ ACE:02. 153 pp.

Irwin, A. J., Z. V. Finkel, O. M. E. Schofield, and P. G. Falkowski (2006), Scaling-up from nutrient physiology to the size-structure of phytoplankton communities, Journal of Plankton Research, 28, 459-471.

Kiorboe, T. and E. Saiz (1995), Planktivorous feeding in calm and turbulent environments, with emphasis on copepods, Marine Ecology Progress Series, 122, 135-145.

Lasker, R. (1975), Field criteria for survival of anchovy larvae - relation between inshore chlorophyll maximum layers and successful first feeding, Fishery Bulletin, 73, 453-462.

Legendre, L. and R. B. Rivkin (2002), Fluxes of carbon in the upper ocean: regulation by food-web control nodes, Marine Ecology Progress Series, 242, 95-109.

Lewis, M. R., W. G. Harrison, N. S. Oakey, D. Hebert, and T. Platt (1986), Vertical nitrate fluxes in the oligotrophic ocean, Science, 234, 870-873.

Muller-Karger, F. E., R. Varela, R. Thunell, R. Luerssen, C. M. Hu, and J. J. Walsh (2005), The importance of continental margins in the global carbon cycle, Geophysical Research Letters, 32, 4.

Muller-Navarra, D. C., M. T. Brett, A. M. Liston, and C. R. Goldman (2000), A highly unsaturated fatty acid predicts carbon transfer between primary producers and consumers, Nature, 403, 74-77.

Munk, W. H., and G. A. Riley (1952), Absorption of nutrients by aquatic plants, Journal of Marine Research, 11, 215-240.

Nycander, J. (2005), Generation of internal waves in the deep ocean by tides, Journal of Geophysical Research, 110, 9.

Pingree, R. D., P. M. Holligan, G. T. Mardell, and R. N. Head (1976), Influence of physical stability on spring, summer and autumn phytoplankton blooms in Celtic Sea, Journal of the Marine Biological Association of the United Kingdom, 56, 845-873.

Planas, D., S. Agusti, C. M. Duarte, T. C. Granata, and M. Merino (1999), Nitrate uptake and diffusive nitrate supply in the Central Atlantic, Limnology and Oceanography, 44, 116-126. 
Platt, T., C. Fuentes-Yaco, and K. T. Frank (2003) Spring algal bloom and larval fish survival. Nature, 423, 398-399.

Poulton, A. J., C. M. Moore, S. Seeyave, M. I. Lucas, S. Fielding, and P. Ward (2007), Phytoplankton community composition around the Crozet Plateau, with emphasis on diatoms and Phaeocystis, Deep-Sea Research II, 54, 2085-2105, doi:10.1016/j.dsr2.2007.06.005.

Reid, D. G. (2001), SEFOS - shelf edge fisheries and oceanography studies: an overview, Fisheries Research, 50, 1-15.

Rippeth, T. P. (2005), Mixing in seasonally stratified shelf seas: a shifting paradigm, Philosophical Transactions of the Royal Society A, 363, 2837-2854.

Sharples, J., C. M. Moore, E. R. Abraham (2001a), Internal tide dissipation, mixing, and vertical nitrate flux at the shelf edge of NE New Zealand. Journal of Geophysical Research, 106, 14,069-14,081.

Sharples, J., C. M. Moore, T. P. Rippeth, P. M. Holligan, D. J. Hydes, N. R. Fisher, and J. H. Simpson (2001b), Phytoplankton distribution and survival in the thermocline, Limnology and Oceanography, 46, 486-496.

Sharples, J., J. F. Tweddle, J. A. M. Green, M. R. Palmer, Y-N. Kim, A. E. Hickman, P. M. Holligan, C. M. Moore, T. P. Rippeth, J. H. Simpson, and V. Krivtsov (2007), Spring-neap modulation of internal tide mixing and vertical nitrate fluxes at a shelf edge in summer, Limnology and Oceanography, 52, 1735-1747.

Tarran, G. A., M. V. Zubkov, M. A. Sleigh, P. H. Burkill, and M. Yallop (2001), Microbial community structure and standing stocks in the NE Atlantic in June and July of 1996, Deep-Sea Research II, 48, 963-985.

Walsh, J.J. (1991), Importance of continental margins in the marine biogeochemical cycling of carbon and nitrogen, Nature, 350, 53-55.

Zubkov, M. V., M. A. Sleigh, P. H. Burkill, and R. J. G. Leakey (2000), Picoplankton community structure on the Atlantic Meridional Transect: a comparison between seasons, Progress in Oceanography, 45, 369-386. 